\title{
Geology and sedimentary history of Lake Traunsee (Salzkammergut, Austria)
}

\author{
Jürgen Schneider ${ }^{1}$, Jens Müller ${ }^{2} \&$ Michael Sturm ${ }^{3}$ \\ ${ }^{1}$ Institut für Geologie und Dynamik der Lithosphäre, Goldschmidtstraße 3, D-3400 Göttingen, FRG \\ ${ }^{2}$ Lehrstuhl für Geologie, Technische Universität München, Lichtenbergstraße 4, D-8046 Garching, FRG \\ ${ }^{3}$ EAWAG-ETH Zürich, Überlandstraße 133, CH-8600 Dübendorf, Switzerland
}

Keywords: lake sediments, clastic deposits, sediment echography, turbidities, sedimentary history

\begin{abstract}
Traunsee was formed by glacial overdeepening of a pre-existing fault system. Present-day morphology is characterized by a deep $(189 \mathrm{~m})$ narrow trough with steep slopes $\left(>50^{\circ}\right)$ in the southern part surrounded by the Northern Calcareous Alps. The northern part of the lake is bordered by flysch and glacial deposits with gentle slopes $\left(<30^{\circ}\right)$ and exhibits several ridges, basins and troughs.

During the late and postglacial period, more than $45 \mathrm{~m}$ of sediment has accumulated in the central basin. Sedimentation in the southern part of Traunsee is mainly controlled by the river Traun forming a prograding delta in the south and - within the past 50 years - by industrial tailings consisting mainly of calcite. Sediments are distributed by undercurrents and by turbidites. Cores from the central basin thus show an intercalation of Traun-derived dolomite-rich sediments with anthropogenic muds from the tailings deposited up to more than $6 \mathrm{~km}$ from its source.

Within the northern basin, land slides from the flysch region played an important role leading to drastic changes in the morphology of slopes and adjacent basins. These slumps have persisted until historic times. Sedimentation in the shallow sublittoral regions is dominated by benthic biogenic decalcification.

The frequency of turbidite sedimentation within the profundal basin decreased during the last 200 years probably due to man's activities in the drainage area such as regulation of rivers and torrents. Sedimentation rates during the past decades range from $2-3 \mathrm{~cm} / \mathrm{a}$ in the southern basin to $0.4 \mathrm{~cm} / \mathrm{a}$ in the northern part as shown by ${ }^{137} \mathrm{Cs}$-dating.
\end{abstract}

\section{Geologic setting, morphology and hydrography}

The Traunsee is situated at the northern rim of the Alps. It is bordered to the south by the Northern Calcareous Alps and the northern part is surrounded by flysch and glacial deposits (Fig. 1, Baumgartner, 1984). The N-S extending basin follows a major transverse fault system which has been eroded and shaped during glaciation. Rock types surrounding the lake reflect the morphology of the present-day basin (see Fig. 2 and Fig. 3 a/b).

The steep slopes of the Northern Calcareous Alps continue below the lake level down to the profundal zone. Dives with the submarine GEO showed the existence of steep slopes $\left(>50^{\circ}\right)$ and even vertical walls with only local sediment cover. Accumulation of sediments from the major tributary - the river Traun - along the eastern border of the profundal zone causes a NW dipping of the basinal plain in the southern part. The narrow trough widens in the central part forming a $189 \mathrm{~m}$ deep central basin plain which is bordered in the north by ridges. Slope angles decrease distinctly in the northern part of the lake where moraines and flysch border the lake. Within this part of the lake several ridges reaching into shallow water depths are separated by smaller basins (see Fig. 2).

Traunsee has the second largest area $\left(24.4 \mathrm{~km}^{2}\right)$ of all the Austrian Alpine lakes. Its volume totals $2228 \times 10^{6} \mathrm{~m}^{3}$, the greatest depth is $189 \mathrm{~m}$. Major 


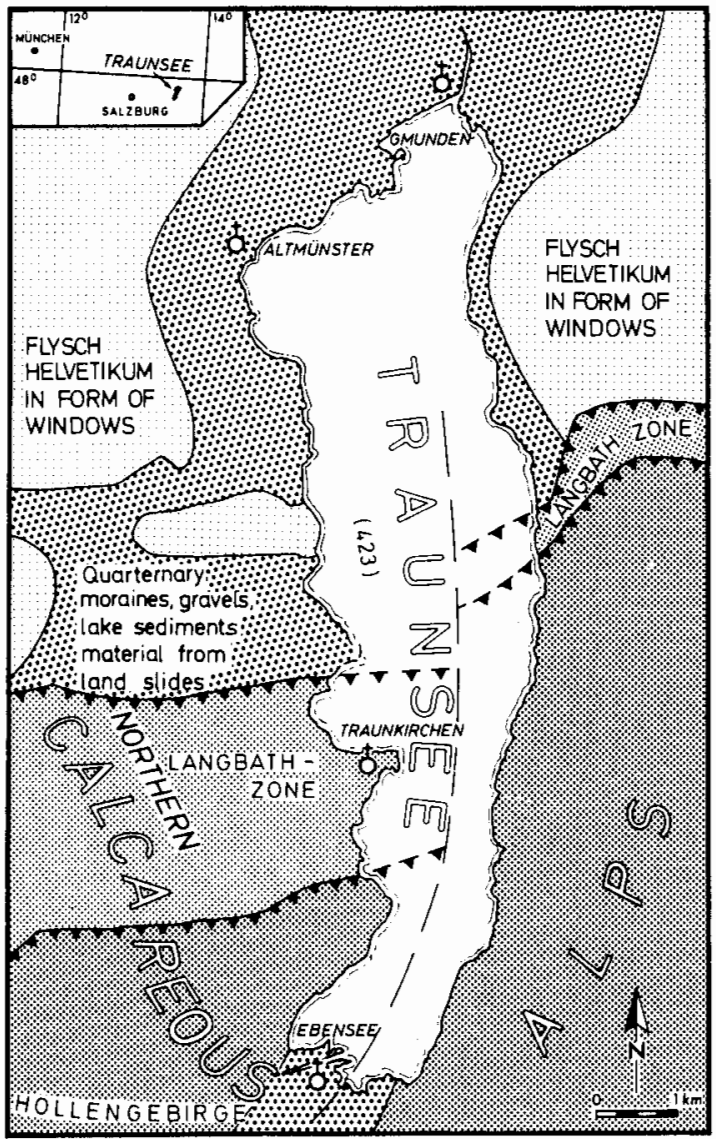

Fig. 1. Geological sketch map of the region around Traunsee (from Baumgartner, 1984).

inflow $(80 \%)$ comes from the river Traun, draining an area of $1417 \mathrm{~km}^{2}$. Mean discharge amounts to $65 \mathrm{~m}^{3} / \mathrm{sec}$ transporting approx. $43000 \mathrm{t} / \mathrm{a}$ of suspended load into the lake. Bed load transport averages 36000 t/a (Baumgartner, 1984; Müller, Sossau \& Zeh, 1983).

The flow of the river Traun into the lake causes a depression of the thermocline and a short residence time $(0.9 \mathrm{a})$. The resulting exchange rate keeps Traunsee at a mesotrophic level in spite of substantial nutrient loading (Pechlaner \& Sossau, 1982).

\section{Sediment sources and sedimentation processes}

Sediments are supplied by different sources and

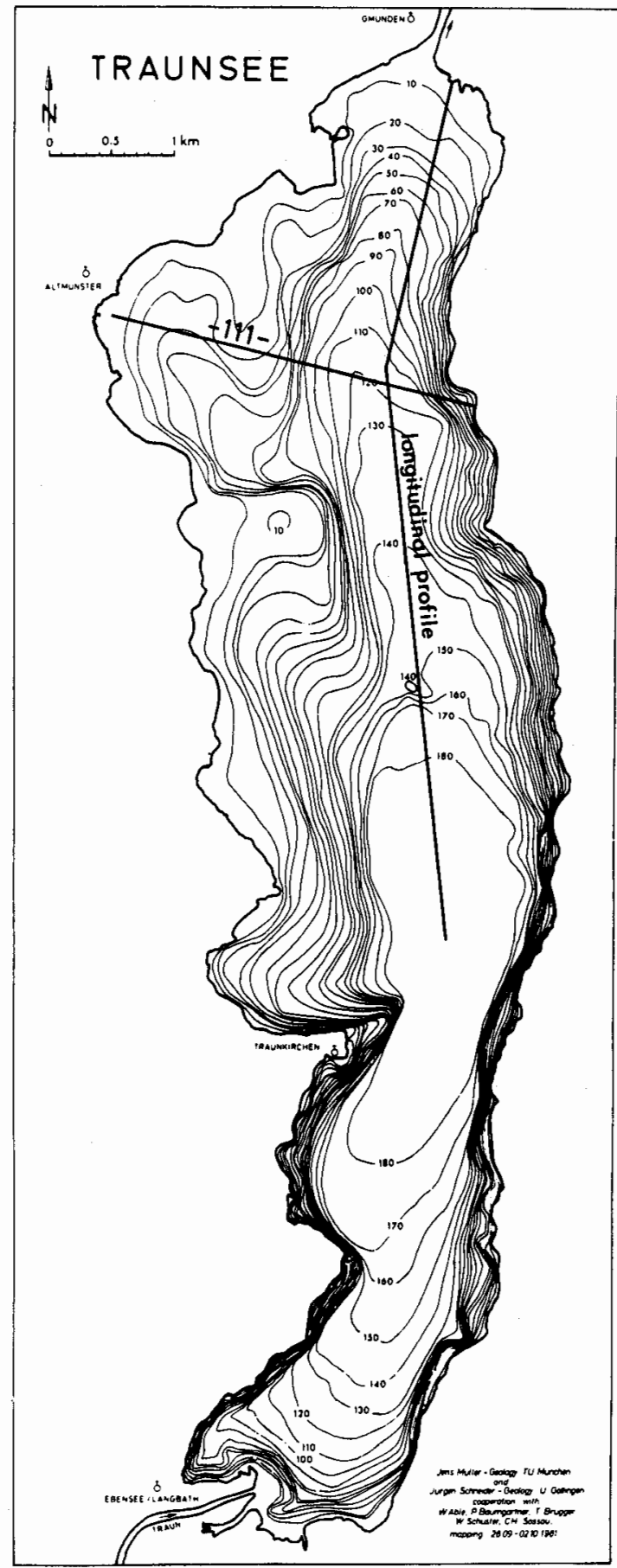

Fig. 2. Bathymetric map of Traunsee showing the position of two sediment echography profiles (Figs. 5 and 7) (from Müller \& Schneider, 1984). 


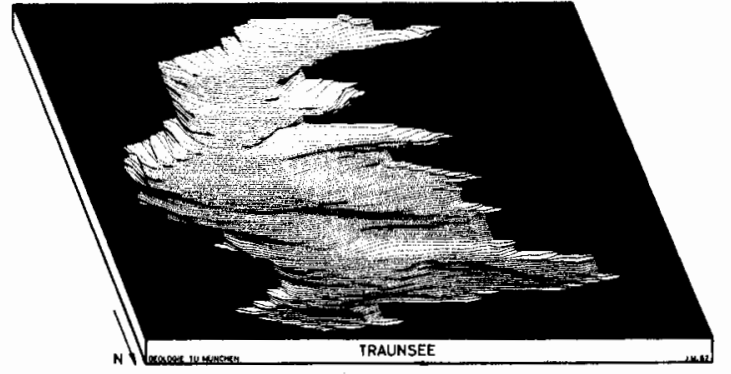

Fig. 3a. 3D computer graph of the Traunsee, viewed from North to South (from Müller \& Schneider, 1984).

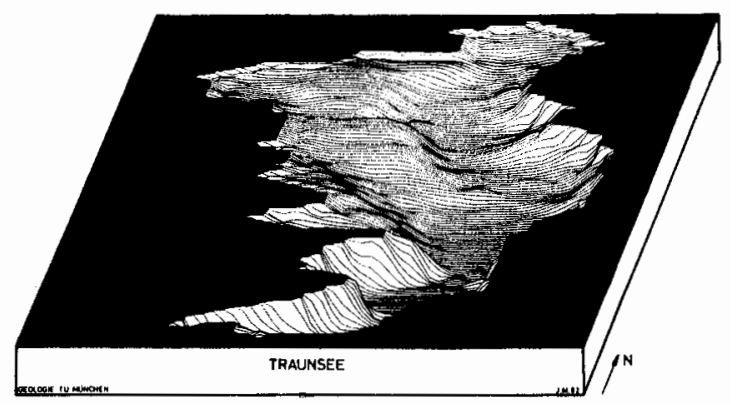

Fig. 3b. 3D computer graph of the Traunsee, viewed from South to North (from Müller \& Schneider, 1984).

mechanisms which are shown in Fig. 4 (see also Claes \& Kersting, 1981). Allochthonous components are derived from natural sources such as the Traun river or other smaller rivulets and by sliding of unstable rock resp. sediment masses or by anthropogenic wastes. The latter come from a limestone quarry and from the combined tailings of soda works and salt works (Müller \& Schneider, 1984).

Autochthonous sediment sources are biogenic epilimnetic decalcification and, in sublittoral regions, biogenic benthic decalcification.

1. Due to the petrography of the drainage area, dolomite is the most important clastic component of the river Traun. Deposition of Traun-derived sediments can thus be traced by the high dolomite content of basin sediments since no other substantial dolomite source exists. Most of the coarse suspended load and the bed load of the river Traun accumulates in the delta area forming foresets with $30^{\circ} \mathrm{dip}$ slopes. Episodic slumps in the foreset area continue into the profundal basin as turbidity cur-

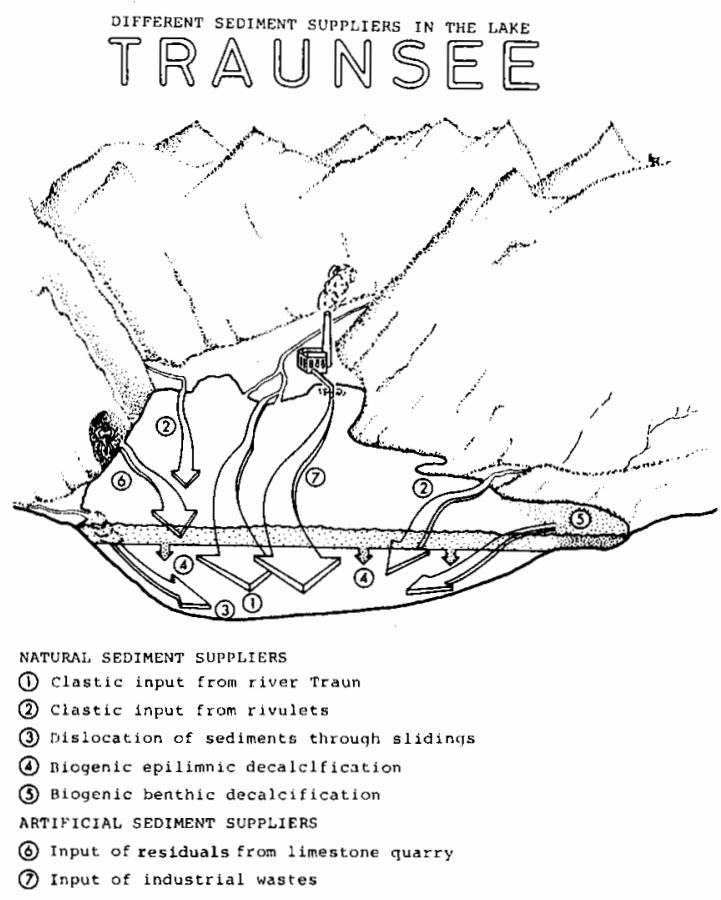

Fig. 4. Natural and artificial sediment suppliers of the Traunsee (modified after Schneider, Claes \& Kersting, 1984).

rents often initiating additional slumps by erosion. Depending upon grain size, fine particles are transported by currents further north before they settle to the ground. Occasional turbidity underflows occur when river water is cold and extremely loaded with fines. In these instances, sediments are transported directly into the central basin.

The extension of turbidites and turbidity underflows is controlled by the basin morphology. Turbidites originating from the south are thus restricted to the northern end of the central basin due to the ridge separating the northern basin from the deeper southern basin (Sturm \& Müller, 1984, Fig. 5).

2. Sediment input of rivulets is restricted both regionally and with respect to the amount deposited. Due to differences in the geology of the respective drainage area sediment distribution from the rivulets can be traced by their specific mineralogical association. Abundance in quartz characterizes catchment areas with flysch outcrops while those coming from moraine areas or from the Calcareous Alps are distinctly lower in quartz and dominated by dolomite and calcite (Fig. 6). 


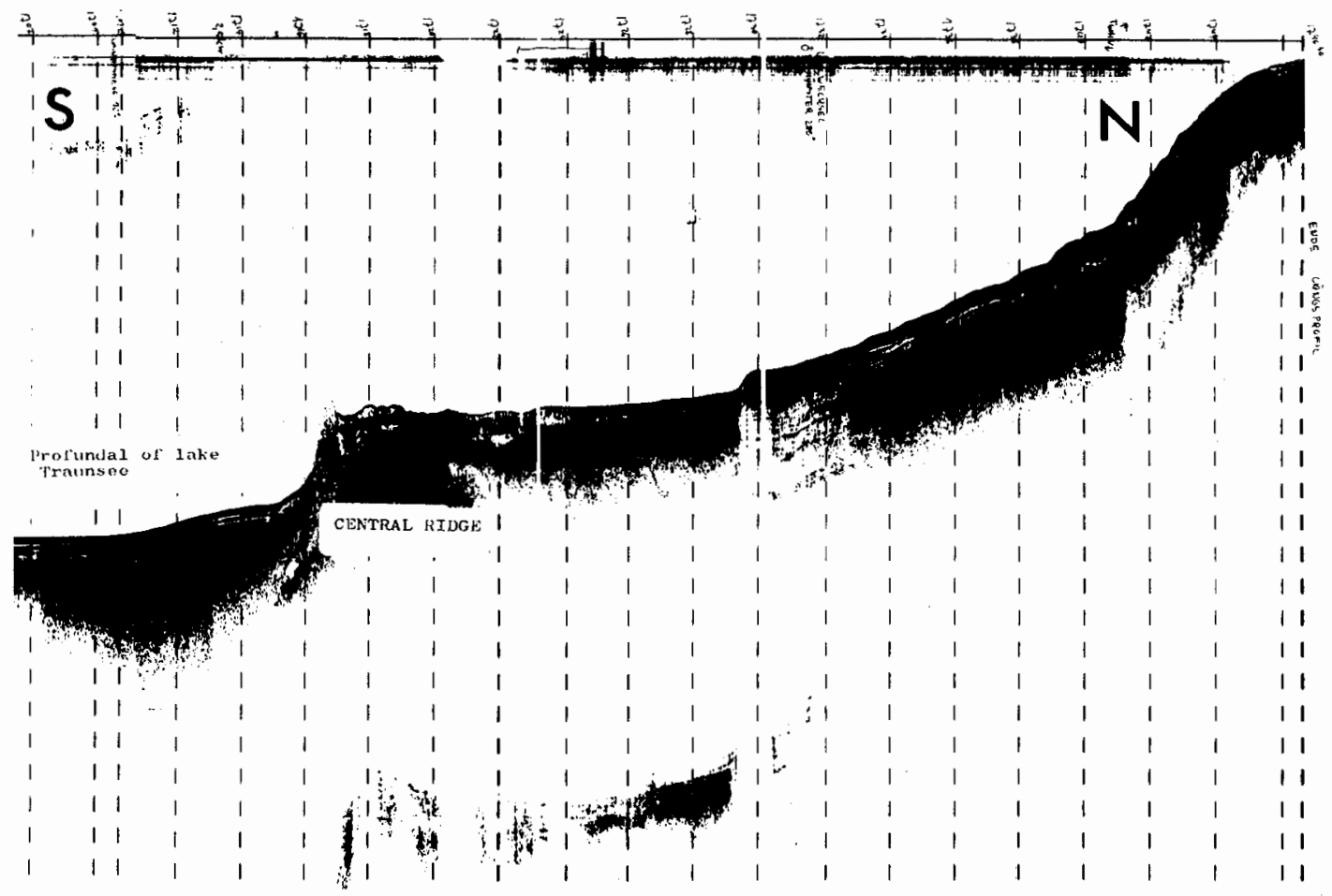

Fig. 5. Part of a longitudinal profile (see Fig. 2) from sediment echography ( $3.5 \mathrm{KHz}$ ORE). The central ridge separates the profundal from the northern basin. Height of the ridge: about $30 \mathrm{~m}$ (from Müller \& Schneider, 1984).

3. Landslides reaching into the lake are a common feature in the flysch zone at the northeastern side of the lake. These slumps have been active for centuries. The last catastrophic event occurred in 1910 when houses slid into the lake. Cores and profiling with $3.5 \mathrm{Khz}$ echosounder showed numerous subaquatic slumps below a sequence of undisturbed lake sediments in the adjacent slope and basin documenting the frequency of slumps in the past (Fig. 7).

4. Biogenic epilimnetic decalcification is best developed during the summer. Increased phytoplankton production reduces $\mathrm{CO}_{2}$ and $\mathrm{HCO}_{3}^{-}$leading to an increase in $\mathrm{pH}$ and subsequent oversaturation causing the precipitation of calcite (e.g. Schröder, Windolph \& Schneider, 1983). Sediment input by this mechanism is however considered to be rather low due to the dilution with allochthonous material in Traunsee.

5. Biogenic benthic decalcification is restricted to the photic zone of shallow sublittoral areas bordering the northwestern and northern part of Traunsee. Calcite precipitation is initiated by the activity of macro- and microphytes leading to the formation of lake marl and chalk in these areas (Schröder, 1982; Schneider, Schröder \& Le Campion-Alsumard, 1983).

6. An additional source of calcite in the southern part of the lake comes from a limestone quarry (Karbach) operated by the soda works. Approx. $12500 \mathrm{t} / \mathrm{a}$ of calcite $<1 \mathrm{~mm}$ is washed into the lake forming a distinct fan in the bottom sediments.

7. Calcite is also the major constituent of the industrial tailings accumulating in the bay of Ebensee in the southwestern corner of Traunsee. The tailings come from soda works and salt works located in Ebensee which have been pumping their solid and dissolved wastes into the lake for more than 50 years. These tailings are of special relevance for the lake ecosystem with respect to their input rate (max. $140000 \mathrm{t} / \mathrm{a}$ solid tailings, $244000 \mathrm{t} / \mathrm{a}$ dissolved wastes), their chemistry (highly alkaline pore waters, $\mathrm{pH}$-values up to 12 ) and their unstable accumulation triggering turbidity currents and slumps reaching the central basin. Their alkaline environment thus influences benthic life in wide 


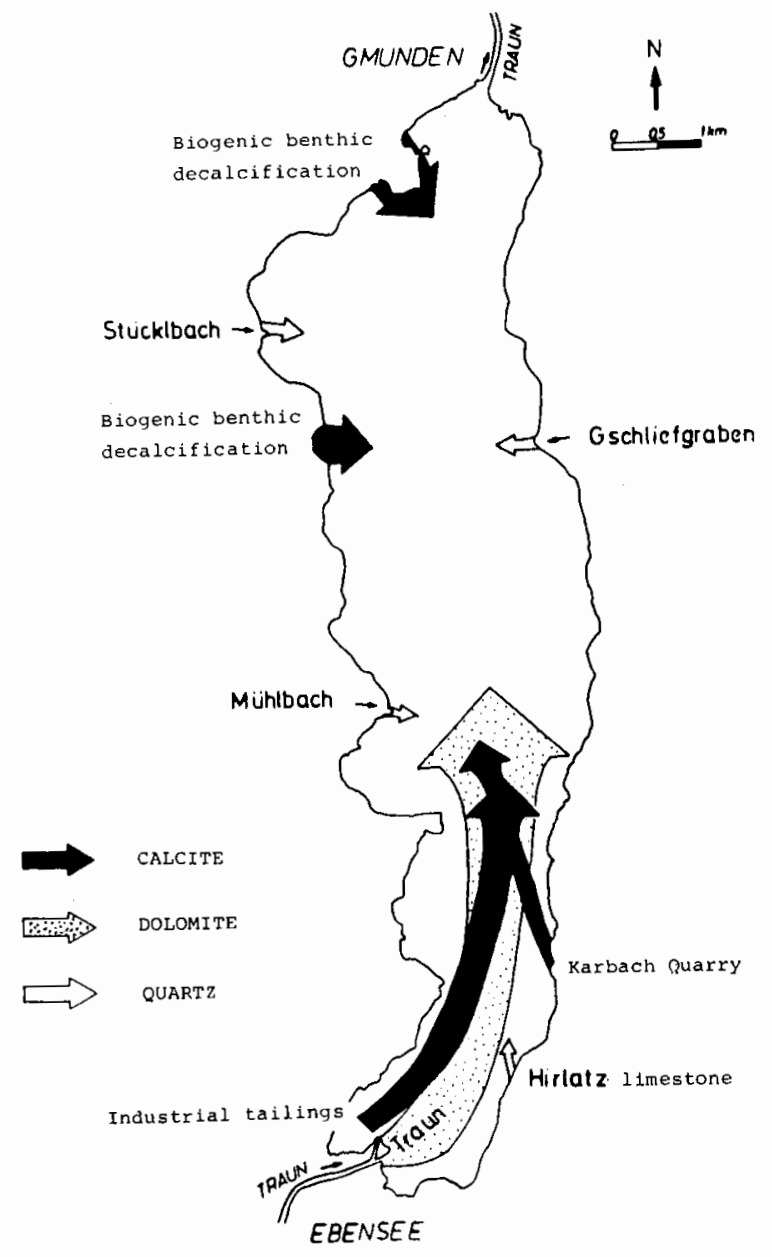

Fig. 6. The main suppliers of calcite, dolomite and quartz into the Traunsee (from Claes \& Kersting, 1981).

portions (approx. 15\% of lake floor) of the lake. (For further details see Müller, Schneider \& Sturm, this volume.)

\section{Sedimentary history and sedimentation rates}

According to van Husen (1977) melting resp. retreat of the Traun glacier occurred rather fast and by 18000 years B.P. the lake was free of ice. A drill site situated approx. $1.5 \mathrm{~km}$ south of the presentday Traun-delta revealed the presence of delta foreset sediments down to a depth of $155 \mathrm{~m}$ overlaying bottomset sediments and glaciofluvial deposits (Baumgartner, 1984). Availability of abundant unconsolidated glacial deposits lacking soil and vegetation cover certainly favoured a high sedimentation rate at the beginning of the late glacial period. $3.5 \mathrm{KHz}$ profiling showed within the present-day central basin sediment thickness exceeding $45 \mathrm{~m}$. Glacial overdeepening thus reached down to $190 \mathrm{~m}$ above sea level; initial lake depth exceeded $235 \mathrm{~m}$ in this lake section.

Since these sediment thicknesses are beyond the

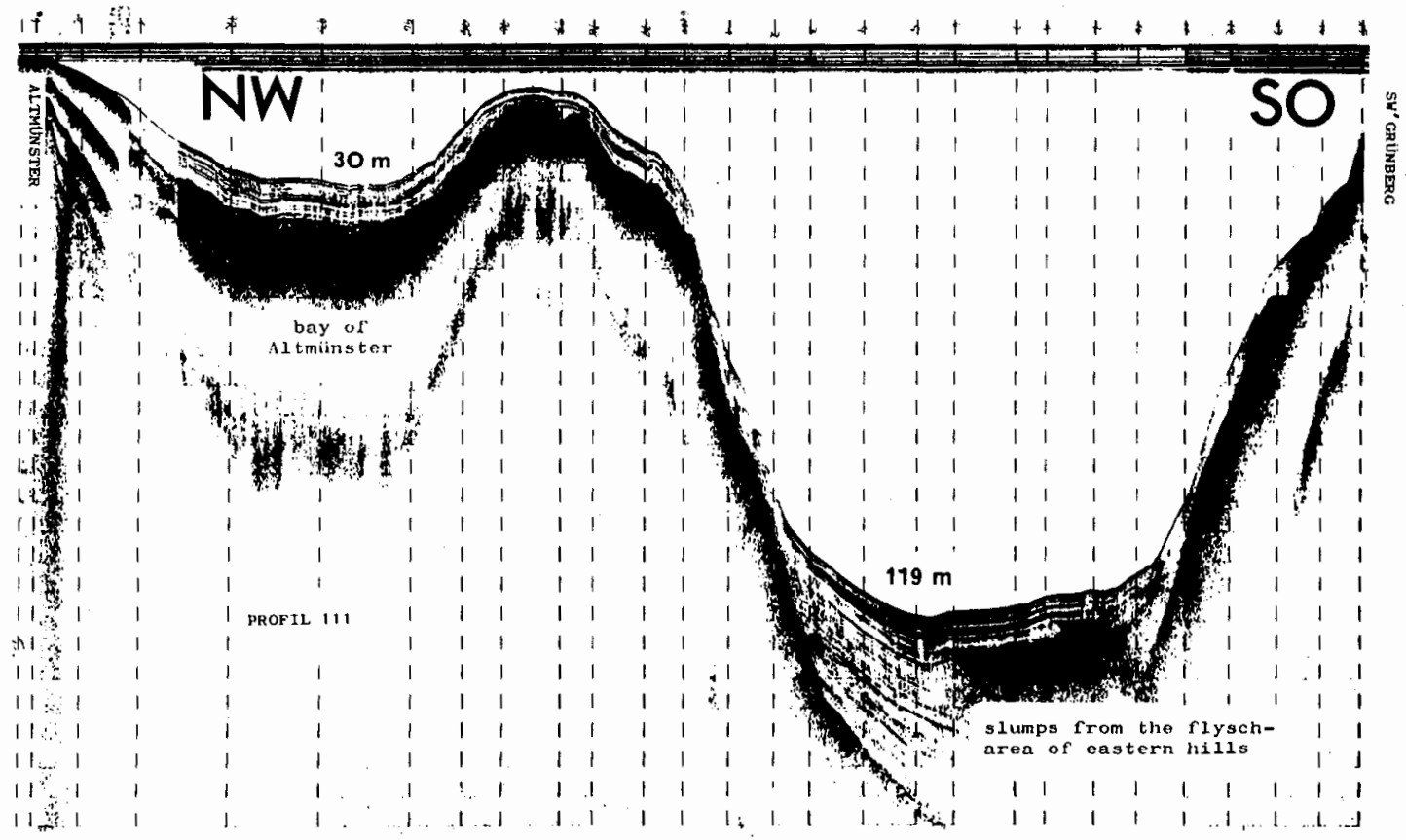

Fig. 7. Cross profile (see Fig. 2) from sediment echography (3.5 KHz ORE) through the northern part of Traunsee. Historical slumps from the flysch area are clearly documented (from Schneider, Claes \& Kersting, 1984, ORE: Dr. J. Müller). 
reach of conventional coring techniques information about the sedimentation during the early stages comes mainly from $3.5 \mathrm{kHz}$ profiling (Müller \& Schneider, 1984).

Records from the central basin reveal sequences of coherent parallel reflectors which document that basin fill occurred mainly by turbidity currents coming from the south. Profiles from the northern basin resp. trough indicate that subaqueous slumps originating from the flysch area played a major role in the past shaping slope and basin morphology (Fig. 7).

Piston coring down to a sediment depth of $6 \mathrm{~m}$ showed that turbidites and slumps prevailed in these sections as well. However, a decreasing frequency of thick $(>5 \mathrm{~cm})$ turbidites in the uppermost sediments of the central basin indicates that consolidation of erosion and weathering processes paralleled by the introduction of effective river regulation and avalanches breaks led to a decrease in these episodic sedimentation events during the past 200 years.

Turbidites originating from the industrial tailings led to a substantial increase in the sedimentation rate of the profundal basin within the past 50 years (Müller \& Schneider, 1984).

Locally, more than $75 \%$ of the uppermost sediment depth consists of the alkaline mud. Sedimentation rates as calculated for this area range from $2-3 \mathrm{~cm} / \mathrm{a}$. ${ }^{137} \mathrm{Cs}$-dating of cores from the northern basin where turbidites are less frequent showed that rates in this area amount to $0.4 \mathrm{~cm} / \mathrm{a}$ (Sturm \& Müller, 1984).

\section{Acknowledgements}

The investigations were supported by a grant of the 'Amt der Oberösterreichischen Landesregierung' (AZ: Bau 2-12106/18-1980/Wei/St.).

\section{References}

Baumgartner, P., 1984. Geologische Verhältnisse in der Umgebung des Traunsees. Limnologische Untersuchung Traunsee-Traun, Amt O. Ö. Landesregierung Bericht Nr. 12: $1-9$.

Claes, M. \& G. Kersting, 1981. Die Sedimente des Traunsees. (Österr. Kte. 1:25000, Bl. 66/2 Gmunden und Bl. 66/4 Ebensee Salzkammergut, Oberösterreich). Diplomarbeit Univ. Göttingen, $205 \mathrm{pp}$.

Husen, D. van, 1977. Zur Fazies und Stratigraphie der jungpleistozänen Ablagerungen im Trauntal. Jb. Geol. B.-A., Wien, 120/1: 1-130.

Müller, J., C. Sossau \& U. Zeh, 1983. Die Schwebstoffe der Traun und des Traunsees. Limnologische Untersuchung Traunsee-Traun, Amt O. Ö. Landesregierung Bericht Nr. 11: $50 \mathrm{pp}$.

Müller, J. \& J. Schneider, 1984. Die Industrieschlammablagerungen in der Bucht von Ebensee und im Profundal des Traunsees (Oberösterreich). Limnologische Untersuchung Traunsee-Traun, Amt O. Ö. Landesregierung Bericht Nr. 12a: 100 pp.

Pechlaner, R. \& C. Sossau, 1982. Die Ergebnisse der fünfjährigen Studie 'Limnologische Untersuchung Traunsee-Traun'. Limnologische Untersuchung Traunsee-Traun, Amt O. Ö. Landesregierung Bericht Nr. 13: 234 pp.

Schneider, J., H. G. Schröder \& T. Le Campion-Alsumard, 1983. Algal micro-reefs - coated grains from freshwater environments. In T. M. Peryt, (Ed.), Coated grains, Springer Berlin, Heidelberg: 284-298.

Schneider, J., M. Claes \& G. Kersting, 1984. Die Sedimente des Traunsees. Limnologische Untersuchung Traunsee-Traun, Amt O. Ö. Landesregierung Bericht Nr. 12: 11-52.

Schröder, H. G., H. Windolph \& J. Schneider, 1983. Bilanzierung der biogenen Karbonatproduktion eines oligotrophen Sees (Attersee, Salzkammergut - Öster reich). Arch. Hydrobiol. $97: 356-372$.

Schröder, H. G., 1982. Biogene benthische Entkalkung als Beitrag zur Genese limnischer Sedimente. Beispiel: Attersee (Salzkammergut, Oberösterreich). Dissertation Univ. Göttingen, $179 \mathrm{pp}$.

Sturm, M. \& J. Müller, 1984. Die Untersuchung langer Sedimentprofile und die Verbreitung von Turbiditen im Traunsee. Limnologische Untersuchung Traunsee-Traun, Amt O. O. Landesregierung Bericht Nr. 12: 97-131.

Accepted 18 March 1986. 